\title{
The Importance of Using Latest Technology in the Contemporary Study of Islamic Theology
}

Mohd Hasrul Shuhari, Mohammed Muneer'deen Olodo Al-Shafi'i, Muhammad Hafizi Rozali, Siti Hajar Mohamad Yusoff \& Mohd Manawi Mohd Akib

To Link this Article: http://dx.doi.org/10.6007/IJARBSS/v11-i2/8664

DOI:10.6007/IJARBSS/v11-i2/8664

Received: 10 December 2020, Revised: 03 January 2021, Accepted: 19 January 2021

Published Online: 08 February 2021

In-Text Citation: (Shuhari et. al., 2021)

To Cite this Article: Shuhari, M. H., Al-Shafi'i, M. M. O., Rozali, M. H., Yusoff, S. H. M., \& Akib, M. M. M. (2021). The Importance of Using Latest Technology in the Contemporary Study of Islamic Theology. International Journal of Academic Research in Business and Social Sciences, 11(2), 212-220.

\section{Copyright: (c) 2021 The Author(s)}

Published by Human Resource Management Academic Research Society (www.hrmars.com)

This article is published under the Creative Commons Attribution (CC BY 4.0) license. Anyone may reproduce, distribute, translate and create derivative works of this article (for both commercial and non-commercial purposes), subject to full attribution to the original publication and authors. The full terms of this license may be seen

at: http://creativecommons.org/licences/by/4.0/legalcode

Vol. 11, No. 2, 2021, Pg. 212 - 220

Full Terms \& Conditions of access and use can be found at http://hrmars.com/index.php/pages/detail/publication-ethics 


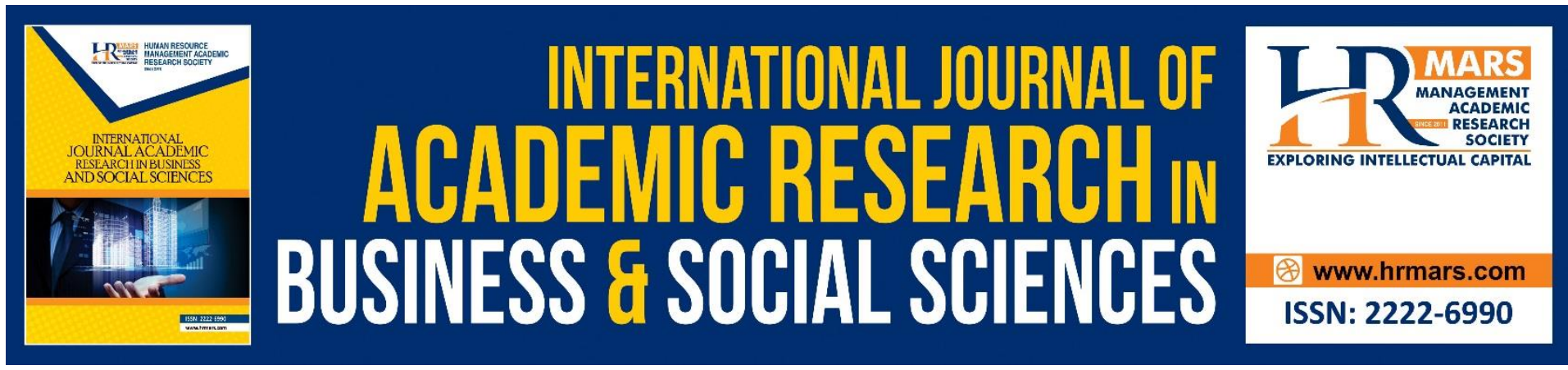

\title{
The Importance of Using Latest Technology in the Contemporary Study of Islamic Theology
}

\author{
Mohd Hasrul Shuhari, Mohammed Muneer'deen Olodo Al- \\ Shafi'i, Muhammad Hafizi Rozali, Siti Hajar Mohamad Yusoff \& \\ Mohd Manawi Mohd Akib \\ Faculty of Islamic Contemporary Studies (FKI), University of Sultan Zainal Abidin (UniSZA), \\ Gong Badak Campus, 21300 Kuala Nerus, Terengganu, Malaysia, The National University of \\ Malaysia (UKM), 43600 UKM, Bangi Selangor, Malaysia. \\ Email: hasrulshuhari@unisza.edu.my
}

\begin{abstract}
Islamic theology is an important aspect of Islam in addition to sharia and morality. It is the most important aspect of Islam. The use of contemporary technology should be used to make it easier for Muslims to understand. This article aims to explain the importance of using the latest technology in the contemporary study of theology in Islam. This study uses library research methods to collect important data. This article concludes that the current situation presents a high need for contemporary technologies such as augmented reality (AR), games and others to explain the concept of Islamic theology.
\end{abstract}

Keywords: Islamic Theology, Technology, Smartphones, Augmented Reality.

\section{Introduction}

The word technology means the application of scientific knowledge for practical purposes. Technology is also the application of scientific knowledge for practical purposes in agriculture, industry, business, medicine, and so on. Technology can also be defined as a method to deal with technical problems based on advanced scientific research such as using chemical processes, electronic equipment, advanced machining, manufacturing and others. Thus, technology is the development of human knowledge for the purpose of facilitating their daily lives. Technology involves the development of science capable of creating its own world. However, technology cannot evolve without the dynamics of dynamic science (Jasmi, 2014). Technology can be defined as the aspect of production of science that simplifies things for human well-being. This can be achieved if it is done in good faith and used properly (Ibrahim, Nazri \& Basiron, 2018).

The main sources of science and technology in Islam are al-Quran and al-Sunnah and other sources if they do not contradict the two main sources. The growth of science and technology in Islamic history can be seen growing rapidly during the Umayyad and Abbasid Empires. Well-known Islamic scholars have made great contributions in various fields of study such as mathematics, astronomy, medicine, chemistry, physics, engineering and others. This 
clearly shows that Islam strongly encourages its people to advance in science and technology for the advancement of human life (Ibrahim, Nazri \& Basiron, 2018).

\section{The Importance of Using Latest Technology in Learning}

Technology has become a very important necessity of life for everyone who uses it (Priatna et al, 2020). The development of increasingly advanced and sophisticated internet technology services and devices has enabled users such as students to access information and participate in online learning sessions more easily (Sorooshian \& Teck, 2020). Learning involves communication that requires technology that can connect teachers and students. This makes it easier for students to learn things such as morals, language, beliefs and so on. With this latest technology, it is easier for them to communicate with many countries around the world. They can use language to communicate with others around the world (Zakaria et al., 2020).

Before the advent of radio and television, humans relied on print media such as newspapers and magazines to find out the latest information. With the increasing sophistication of technology, the current trends of society are also changing. If it is used in the right way, then Islamic education can be disseminated to the community widely and easily. It helps teachers to teach better based on the sunnah of the Prophet (p.b.u.h). Based on the history of Islam, especially related to the approach of the Prophet (p.b.u.h), it was found that the Prophet (p.b.u.h) also applied various latest approaches aimed at facilitating the delivery of knowledge to his companions (sahabah). The Prophet (p.b.u.h) communicated with the companions based on their intellect and according to circumstances. The developers of information and communication technology (ICT) applications should increase the number of applications related to sunnah education (Hassan et al., 2016).

To improve the level of learning and teaching, the education system has undergone a major evolution in educational technology after the introduction of the concept of Mobile Learning. In Malaysia, it is also experiencing this development even though it is still new. This learning process is not tied to the learning location and it has also been enhanced with the availability of smartphone applications based on Android and iOS platforms. Both platforms are easy for students to find for free Android and iOS applications in their learning. It is very much needed by students because it can increase their interest and motivation in the learning process (Yusoff \& Romli, 2018).

Teaching patterns in schools are mostly teacher-centered. This approach less encourages students to develop their own ideas. If it is a game-based teaching, it is believed that critical thinking and creativity skills can be improved based on the latest technology. Education based on information and communication technology (ICT) also opens space for problem-based learning and self-learning. The technology in learning used needs to be interactive in order to attract students. Students need to have high motivation to keep trying to find a solution to a given problem. If there is no high motivation, they will give up and no longer want to continue the experiment. Thus, game-based and digital learning are introduced to assist them in enhancing creative solutions (Muhamad et al., 2015). In addition, teachers can also assess students through online applications such as mentimeter.com, quizizz.com and others.

\section{The Necessity of Latest Technology in Teaching Contemporary Islamic Theology}

Education is a necessity for every Muslim especially when it comes to understanding their own religion (Khairuldin et al, 2020). Allah s.w.t has glorified the Muslims by making them the best ummah of all nations and sent a revelation to the Prophet Muhammad s.a.w to free them 
from the darkness of disbelief to the light of theology (Al-Shafi'i et al., 2020). So, Muslims need to utilize current technology for strengthening theology and others. This is in accordance with their status as the best ummah (khair ummah).

The use of information technology (IT) has undergone exciting new developments. Technology application developers need to increase the number of applications related to Sunnah education. Thus, this technology can be taken advantage of to explain one of the sunnahs especially in teaching the Islamic theology to mankind (Hassan et al., 2016).

The use of this technology to explain Islamic theology is very important. This is because, the number of people using mobile phones worldwide is around four billion which represents about $70 \%$ of the world's population. They are exposed to various applications for various purposes such as entertainment, business, reference, learning and so on (Aminuddin, Rahman \& Yew, 2015). Therefore, the use of current technology to explain the concept of contemporary Islamic theology is very important.

In addition, using latest technology, knowledge about the contemporary Islamic theology can also be widely disseminated through applications such as Instagram, Facebook, WhatsApp, Telegram, LinkedIn, Line, WeChat, YouTube and others. Users can collect a variety of references, be it primary or secondary, through PDF-based softcopy and Microsoft Words in large numbers. It does not require large physical space such as bookshelves and so on (Haryani \& Triyono, 2017). With the advancement of modern technology, they can store references about this belief on personal computers, tablets, ipads, smartphones and more through the al-Maktabah al-Shamilah application. This provides an opportunity for Islamic preachers to spread the Islamic theology more easily and quickly using modern technology.

Muslims need to play a role in providing information technology applications that explain important information that can enhance understanding of the Islamic theology. It can be used as a tool for preaching. To explain the true theology, many 'applications' can be developed through various methods such as games, infographic videos, documentaries and others. By using smartphone, it is easy to access varieties of information especially when using technologies such as Augmented Reality (AR). With this technology, the information will be displayed interestingly and uniquely. Teaching and learning especially about the concept of the contemporary Islamic theology is also believed to be taught effectively to students using AR technology.

\section{Technology of Augmented Reality (AR) and Islamic Theology}

Almost every individual in society has a smartphone like an android. By using mobile phones, they can use technologies like AR. This technology provides information about something more interesting and unique (Santoso, 2015). Users can visualize objects in three-dimensional (3D) forms. AR technology has interactive and real-time elements that are suitable for use in a variety of fields. The use of this technology has evolved significantly into many aspects of individual life. This is because the use of this AR technology is very attractive and easy for users (Rifa'i, Listyorini \& Latubessy, 2014). Therefore, if it is used in explaining the concept of the contemporary Islamic theology, it can facilitate students' understanding.

According to Haryani and Triyono (2017), the use of information technology (IT) is growing rapidly. One of the latest technologies that can be taken advantage of to know something is augmented reality (AR) technology. AR technology combines real and virtual objects in real environments, aligning real and virtual objects with each other and running interactively in three dimensions (3D), and in real time (Krevelen \& Poelman, 2010). 
The use of AR technology today has evolved into many aspects of an individual's life and its development is very significant (Rifa'i, Listyorini \& Latubessy, 2014). AR technology used in learning is expected to create a learning environment that affects students. To solve problems in understanding a learning topic, AR technology is applied by combining real-world situations and virtual objects (Wardani, 2015). AR technology used through smartphones, can provide information about something interesting and unique. This AR technology also has the advantage to users where they can access information easily and quickly (Santoso, 2015).

If learning process involves learning materials such as faith books that are difficult to read, then this modern technology is pretty good to use. Researchers need to provide modern technology applications that allow readers to understand the book. This effort is also based on the problems of students to understand the book. Modern technology that is thought to help these students is augmented reality (AR) technology.

Among the use of technology in education is to facilitate teaching based on the Sunnah of the Prophet (p.b.u.h.). Rasulullah (p.b.u.h.) also allowed the use of the latest tools to make it easier for his people to understand. Rasulullah (p.b.u.h.) interacted with Muslims based on their respective levels of intellect and situation. Therefore, technology is seen as one that can be used to explain one of the sunnah, especially in introducing and teaching theology for example based on the book Kubra al-Yaqiniyyat.

In Islamic studies, this technology is still less applied in learning and teaching (Khairuldin et al, 2019). In order to further increase the number of applications of technology in Islamic education, especially in the field of theology learning, AR technology needs to be utilized. Then, the study of its effectiveness needs to be implemented so that Islamic theology education is not left behind in utilizing modern technology. The use of AR technology as an example, is expected to benefit students, especially those who use the book Kubra alYaqiniyyat to understand the contemporary Islamic theology. This application can also be used by academics and the public who are interested in the book and its author, Sheikh Prof. Dr. Muhammad Sa'id Ramadan al-Buti.

The next subtopic briefly describes an example of the construction of AR technology application in understanding one of the books of theology, namely Kubra al-Yaqiniyyat written by Muhammad Sa'id Ramadan al-Buti.

\section{MySyakhsiyyah Augmented Reality (AR) application related to Contemporary Islamic Theology}

MySyakhsiyyah Augmented Reality (AR) application related to Islamic theology was created to facilitate teaching and learning for students of the Faculty of Contemporary Islamic Studies, Sultan Zainal Abidin University (UniSZA), Terengganu, Malaysia. This application was developed based on the Book of Kubra al-Yaqiniyyat written by Muhammad Sa'id Ramadan al-Buti. This application is based on a marker where the selected sheet of paper when it is scanned with a smartphone, it will explain something in various multimedia elements including audio, video, text and graphics. Here it will be explained in detail the construction of MyShakhsiyyah AR Application regarding contemporary Islamic theology. In the development of this application, there are some very important software and hardware to use. Table 1 describes the hardware used to develop this application, while Table 2 describes the software used to develop this application 
Table 1

\begin{tabular}{|l|l|l|}
\hline & Hardware & Use \\
\hline 1 & Laptop & $\begin{array}{l}\text { To create the sketches for the characters, background and create } \\
\text { scripts or documents related to the application. Also used for on } \\
\text { the go coding and 3D modelling. }\end{array}$ \\
\hline 2 & External Hard Disk & To backup all project data. \\
\hline 3 & $\begin{array}{l}\text { Personal } \\
\text { Computer }\end{array}$ & $\begin{array}{l}\text { Used to code, render and create the overall interface. A PC is } \\
\text { needed as the project is heavy and requires strong rendering } \\
\text { power that could not be provided with a laptop. }\end{array}$ \\
\hline 4 & Headphones & $\begin{array}{l}\text { Used for development and test runs of the projects as well as used } \\
\text { for the finished project to amplify immersion. }\end{array}$ \\
\hline 5 & Mobile Phone & To run and test the application. \\
\hline 6 & Mouse & A mouse is used during the coding and 3D modelling process. \\
\hline
\end{tabular}

Table 2

\begin{tabular}{|l|l|l|}
\hline & Hardware & Use \\
\hline 1 & Unity & $\begin{array}{l}\text { Used to create the Augmented Reality app and overall project and } \\
\text { animate 3D characters }\end{array}$ \\
\hline 2 & Maya 2018 & Used to create 3D models \\
\hline 3 & Google Cloud & Used as an external render models or animations \\
\hline 4 & Adobe Illustrator & To design marker and logo application. \\
\hline 5 & Adobe Photoshop & Used to create sketches of background, characters and posters. \\
\hline 6 & Vuforia Developer & Set the marker \\
\hline
\end{tabular}

The marker is taken from the selected Book Sheets and set in Vuforia Developer. Then it is developed in Unity 3D. we include here the markers that have been set in the Vuforia Developer.
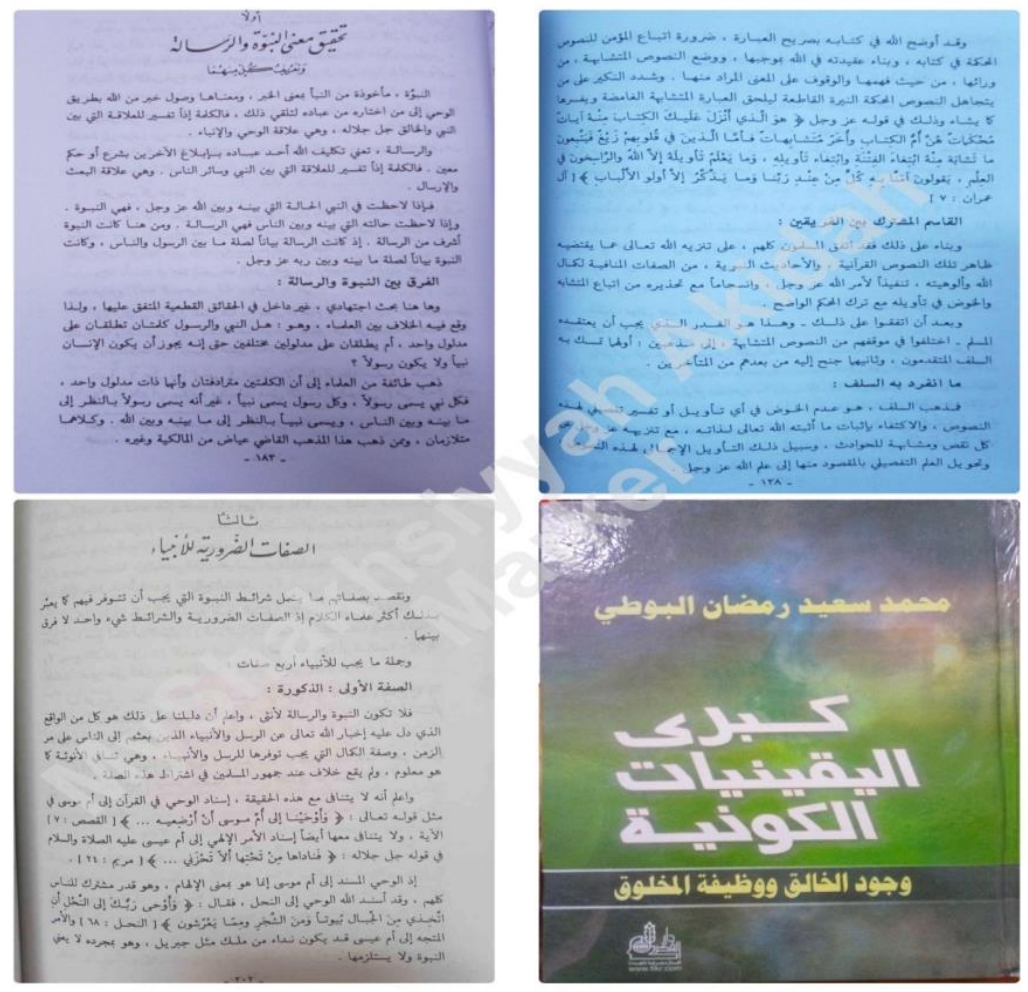
Markers that have been set as databases will produce different outputs according to what has been set. Among them are video, audio translation, voice dictionary and 3D book dimensions on the cover of the Book. Among the outputs or findings that come out based on the selected markers are shown below:
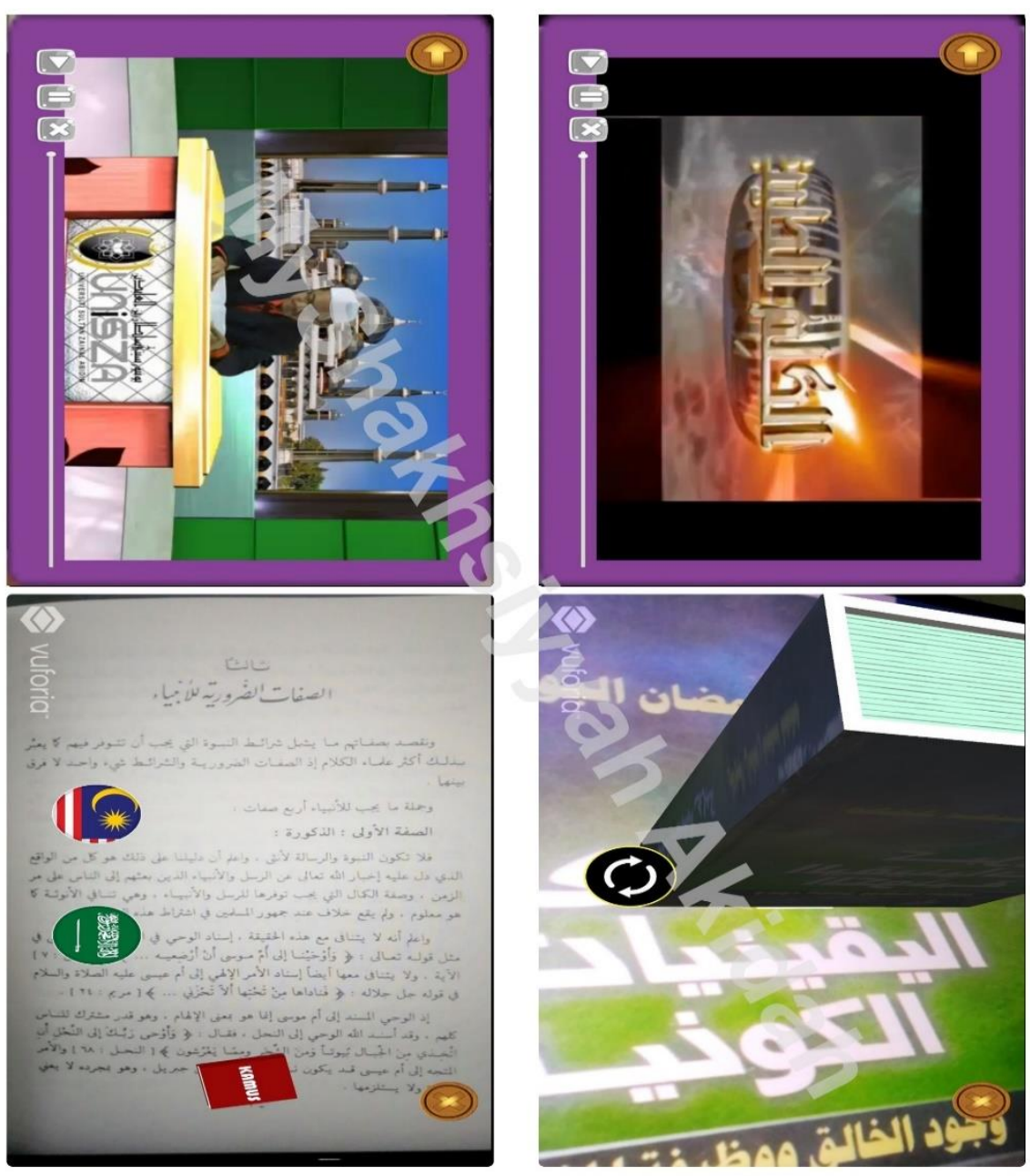

\section{Conclusion}

The use of contemporary technology to understand the Islamic theology is important based on the contemporary situation. However, it does not deny the need for one to learn physically with the teacher, as it is an Islamic tradition we have to maintain and preserve. One of the current technologies that can be utilized is augmented reality technology. This is based on the current reality that many younger generations including Muslims, especially students, are now using smartphones. This makes it easier for them to use augmented reality applications. Therefore, this technology should be used by educators to provide understanding to the younger generation about the contemporary Islamic theology. And one good example of applications built for that purpose is MyShakhsiyyah AR application on Islamic technology.

\section{Acknowledgement}

This paper is funded on the research project of the Scholarship of Teaching and Learning (SoTL), Project Code: UniSZA / 2019 /SoTL / 01. Special appreciation is owed to Universiti Sultan Zainal Abidin (UniSZA), Centre for Management of Academic Excellence and Innovation 
(CoMAE-i) UniSZA and Center for Research Excellence \& Incubation Management (CREIM) UniSZA for sponsoring and supporting this research.

\section{Corresponding Author}

Mohd Hasrul Shuhari

Centre for Usuluddin Studies, Faculty of Islamic Contemporary Studies (FKI), Universiti Sultan Zainal Abidin (UniSZA), Gong Badak Campus, 21300 Kuala Nerus, Terengganu, Malaysia.

Email: hasrulshuhari@unisza.edu.my

\section{References}

Aminuddin, H., Rahman, F., \& Yew, S. K. (2015). Explore logical thinking through the use of mobile applications (Meneroka pemikiran logik melalui penggunaan aplikasi mudah alih), International Journal Of Education And Training (Injet), 1(2), pp. 1-7, November 2015.

Haryani, P., \& Triyono, J. (2017). Augmented reality (ar) as an interactive technology in the introduction of cultural objects to society (Augmented reality (ar) sebagai teknologi interaktif dalam pengenalan benda cagar budaya kepada masyarakat), Jurnal SIMETRIS, Vol. 8 No. 2, pp. 807-812.

Ibrahim, M. I., Nazri, F. I., \& Basiron, B. (2018). Islam and the formation of science and technology (Islam serta pembentukan sains dan teknologi), in Prosiding Seminar Tamadun Islam 2018, pada 17hb. Ogos 2018 di Bilik Kuliah 6, Blok N28, UTM. Program Anjuran Akademi Tamadun Islam, UTM, 2018, pp. 1-12.

Jasmi, K. A. (2014). Education as a medium of Islamic application in science and technology (Pendidikan sebagai medium penerapan islam dalam sains dan teknologi), in Persidangan Islam dalam Sains dan Teknologi 2016 (PIST'16), pada 13-15 Oktober 2016 bertempat di Dewan Senat, Universiti Teknologi Malaysia, Skudai, dianjurkan oleh Kolej Tun Hussein Onn, Universiti Teknologi Malaysia, 2014, pp. 1-19.

Yusoff, A. F., \& Romli, A. B. (2018). Use of mobile apps for Islamic science, technology and engineering courses ( $m$-istech) in polytechnic malaysia (Kebolehgunaan aplikasi mudah alih (mobile apps) bagi kursus sains, teknologi dan kejuruteraan dalam Islam (m-istech) di politeknik malaysia), Attarbawiy: Malaysian Online Journal Of Education, Vol. 2, No. 1 pp. 18-28.

Muhamad, N., Harun, J., Salleh, S. M., \& Zakaria, M. A. Z. M. (2015). Game-based development to improve creative problem solving skills in math (Pembangunan berasaskan permainan bagi meningkatkan kemahiran penyelesaian masalah kreatif dalam matematik). in 2nd International Education Postgraduate Seminar (IEPS 2015), 20-21 Dec, Johor Bahru, Johor, 2015, pp. 1-9.

Al-Shafi'i, O. M. M., Ali, M. S., Zin, E. W. I., Shuhari, M. H., Musa, R., Oladosu-Uthman, H., \& Abdullahi, A. (2020). The concept of wilayah (responsibility) according to ibn taymiyyah, International Journal of Innovation, Creativity and Change, Volume 13, Issue 1, pp. 594607.

Priatna, T., Nurhamzah, Suryana, Y., \& Nurdiansah, N. (2020). Developing management of quran memorization institutionsthrough the web system, International Journal of Advanced Trends in Computer Science and Engineering, Volume 9, No.1, pp. 465-468, January-February 2020. DOI: https://doi.org/10.30534/ijatcse/2020/63912020

Rifa'i, M., Listyorini, T., \& Latubessy, A. (2014). The application of augmented reality technology to android-based home catalog applications (Penerapan teknologi augmented 
reality pada aplikasi katalog rumah berbasis android), in Prosiding SNATIF Ke-1 Tahun 2014. Fakultas Teknik Universitas Muria Kudus, pp. 267-274.

Santoso, D. (2015). Design an augmented reality application to show the writing process of batik (Rancang bangun aplikasi augmented reality untuk menampilkan proses pembuatan batik tulis). M.S. thesis, Program Studi Informatika, Universitas Muhammadiyah Surakarta.

Sorooshian, S., \& Teck, T. S. (2020). Information technology for supply chain management: literature review, International Journal of Advanced Trends in Computer Science and Engineering, Volume 9, No. 1, pp. 80-86, January-February 2020. DOI: https://doi.org/10.30534/ijatcse/2020/13912020

Hassan, S. N., Zakaria, N., Long, M. Y., Goje, K., \& Said, W. (2016). The development of technology applications in the teaching and learning of Hadith in the age of globalization (Pembangunan aplikasi teknologi dalam memantapkan pengajaran dan pembelajaran hadis pada zaman globalisasi), in Seminar Warisan Nabawi (SWAN 2016), At-Fatoni University, Thailand, Vol. 5, pp. 1-10.

Krevelen, D. W. F., \& Poelman, R. (2010). A survey of augmented reality technologies, applications and limitations. The International Journal of Virtual Reality, 2010, 9 (2), pp. 1-20.

Khairuldin, W. M. K. F., Embong, A. H., Anas, W. N. I. W. N., Ismail, D., \& Mokhtar, W. K. A. W. (2019). An augmented reality (ar) approach in educational integration of du'a in Islam. International Journal Of Academic Research In Progressive Education And Development, 8(1), pp. 32-39.

Khairuldin, W. M. K. F., Anas, W. N. I., Embong, A. H., Hassan, A., \& Imas, M. M. (2020). Islamic gamification: application of gamification concepts in Islamic education according to Islamic perspective, TEST Engineering \& Management, Volume 83, pp. 10885-10890.

Wardani, S. (2015). The use of augmented reality (ar) technology for the introduction of java characters for children (Pemanfaatan teknologi augmented reality (ar) untuk pengenalan aksara jawa pada anak). Jurnal Teknologi, Vol. 8, No. 2, pp. 104-111.

Zakaria, R., Ismail, M. S., Zain, M. A. D., Shuhari, M. H., Wahab, M. R., Omar, S. H., Ali, M. S., \& Engku Alwi, E. A. Z. (2020). Relationship effect of demographic factors on self-efficacy of arabic language proficiency. Journal of Critical Reviews, Vol 7,Issue 7, pp. 468-472. 